\title{
Dr. Floyd Avery Peyton In Memoriam
}

On July 13, 1994, the founder and first chairman of the Dental Materials Group of the IADR, Dr. Floyd Avery Peyton, died at the age of 89 at his home in Sun City Center, Florida. Dr. Peyton had developed Parkinson's disease during the last few years of his life, but the cause of death was infectious pneumonia. He was born on February 2, 1905, in Charleston, Indiana. In 1928, he received an A.B. degree in chemistry from Indiana University and, in 1929, received an M.S. in physical chemistry from Michigan College of Mining and Technology. Dr. Peyton moved to Ann Arbor in 1930 to take graduate courses in chemistry toward his doctoral degree. During this time, he served as a research assistant to Dr. Ward and conducted research on dental materials. Dr. Peyton found dental research very interesting, and at the suggestion of Dr. Ward, changed his major from chemistry to dental metallurgy and materials. The first University of Michigan joint doctoral science degree in dentistry and metallurgical engineering, D.Sc., was awarded to Dr. Peyton in 1933.

After graduation, Dr. Peyton accepted a position with the Ames Manufacturing Company in Fermont, Ohio where he developed a less soluble and stronger cement of that time, which was his first contribution to the dental profession. In 1935, he joined the faculty of the University of Michigan School of Dentistry as an instructor and, except for the period between 1945 and 1948 where he taught at the University of Texas Dental School, spent his time on the faculty at Michigan. He held the title of professor and chairman of the Department of Dental Materials from 1948 until his retirement in 1969.

Dr. Peyton was a true pioneer since he played a major role in the development of the field of dental materials, both as a teacher and as a researcher inside and outside of the University of Michigan. He developed and expanded the department's graduate program in dental materials. Under his guidance, the graduate program achieved a reputation as one of the most respected programs of its kind in the world. Graduates of Michigan's dental materials program were leaders in the field, occupying prominent roles in similar dental school departments in the U.S. and abroad. In the 1960's, his laboratory was considered to be one of the best-equipped and betteroperated of its kind.

Dr. Peyton's contributions outside of the University of Michigan are equally noteworthy. He was a visiting professor at San Carlos University of Guatemala and a Fulbright lecturer in Egypt, New Zealand, and India, where he spent a semester in each location and developed their dental materials departments. Dr. Peyton's accomplishments are numerous. When he started his teaching career, dental materials was taught to practicing dentists in a cookbook fashion. He tried and succeeded at introducing some science into the subject. Through the years, Dr. Peyton continued to write numerous papers and booklets on his findings related to dental materials. In 1960, he published a textbook entitled Restorative Dental Materials. From its first year of publication, the textbook became one of the most widely used in this field. Three revisions incorporating newer materials were

made before his retirement. Today the same textbook is edited by Robert Craig and is in its 9 th edition.

After retirement, Dr. Peyton moved to Sun City Center, Florida and, according to Mrs. Peyton, who became his secretary, retired from one full-time position to handle three half-time positions without appointed staff. By invitation of the Dean of the University of Florida College of Dentistry, he accepted a half-time posi-

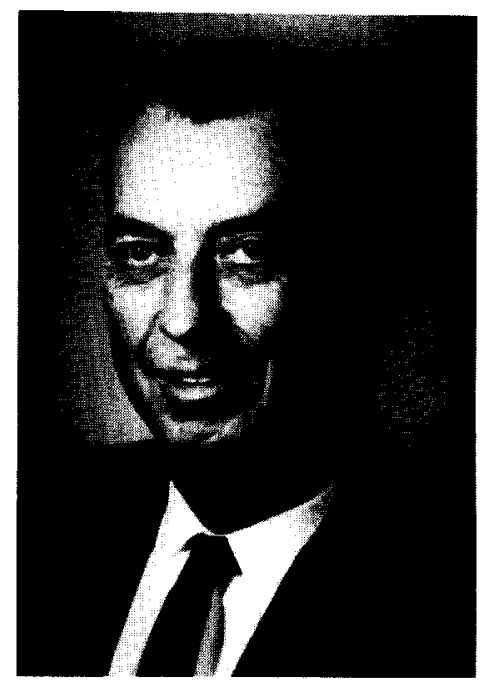
tion and traveled to Gainesville to teach dental materials to dental students and faculty at the college and helped faculty conduct research. He also accepted another half-time position as a volunteer consultant to the Pan American Health Organization. In this capacity, Dr. Peyton traveled many weeks of the year to different countries in Central and South America, making suggestions to both the governments of the countries he visited and to the main office of the organization. He was very supportive of the ADA's specification program and was always ready to test and provide the necessary data to the specification committee and to help establish specifications related to various materials. After his retirement in 1969, he accepted another volunteer position as Chairman of the Accredited Standards Committee for the ADA.

Dr. Peyton was so determined to be successful in his chosen field that he would not allow a medical handicap to hold him back. While at Michigan, he was active in the Boy Scout programs serving as chairman of the Council of the Boy Scouts of America for years. He received the Boy Scouts of America Training Award and also the Beaver Award. He received many additional awards and recognitions. Among these were the Wilmer B. Souder Award of the IADR, the Academy of Plastics Award, several awards of the World and Pan American Health Organization, and the Distinguished Faculty Achievement Award from the University of Michigan. He is also listed in Men of Science - United States. In 1991, the Dental Materials Group of the AADR established an award in clinical research honoring its founder, Dr. Floyd Peyton.

Dr. Peyton was a mentor and friend to many students and faculty members. Numerous foreign students considered Dr. and Mrs. Peyton to be their American parents. Dr. Peyton gave a great deal to the field of dental materials locally, nationally and internationally, but above all he was a very kind, warm gentleman, and a loving husband and father. He will be missed by many.

Kamal Asgar

Protégé and student

University of Michigan
Cara Voss

Dental Materials Department secretary for 18 years 